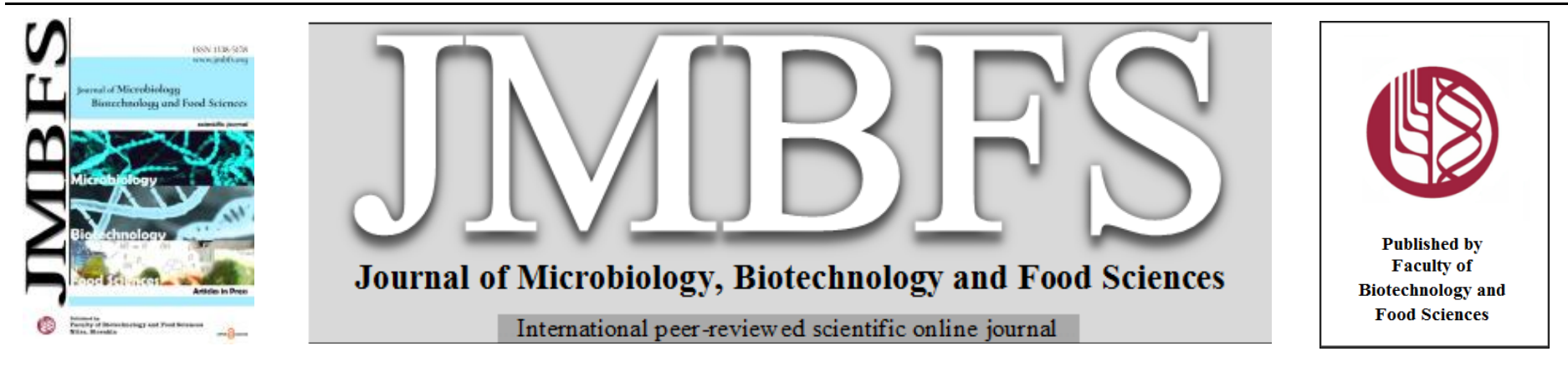

\title{
THE INFLUENCE OF NON-TRADITIONAL FRUITS AND ELDER FLOWERS ON RHEOLOGICAL PROPERTIES OF THE DOUGH
}

\author{
Anna Kolesárová*l, Tatiana Bojňanskál, Jana Kopčeková2, Adriana Kolesárová ${ }^{3}$
}

Address(es): Ing. Anna Kolesárová, PhD.,

${ }^{1}$ Slovak University of Agriculture in Nitra, Faculty of Biotechnology and Food Sciences, Institute of Food Sciences, Trieda A. Hlinku 2, 94976 Nitra, Slovakia.

${ }^{2}$ Slovak University of Agriculture in Nitra, Faculty of agrobiology and Food Resources, Institute of Nutrition and Genomics, Trieda A. Hlinku 2, 94976 Nitra, Slovakia.

${ }^{3}$ Slovak University of Agriculture in Nitra, Faculty of Biotechnology and Food Sciences, Institute of Biotechnology, Trieda A. Hlinku 2, 94976 Nitra, Slovakia.

*Corresponding author: anna.kolesarova@uniag.sk

https://doi.org/10.55251/jmbfs.4671

\section{ARTICLE INFO}

Received 12. 4. 2021

Revised 31. 1. 2022

Accepted 7. 2. 2022

Published 1. 6. 2022

Regular article open $\odot$ access

\section{ABSTRACT}

The influence of the addition of flowers (Flos sambuci L.) and berries of elderberry (Sambucus nigra L.), blackcurrant (Ribes nigrum L.) and chokeberry (Aronia melanocarpa L.) to wheat flour was characterized by the rheological test Mixolab (Chopin Technologies, France). Twelve types of wheat flour mixture with different fruit and elder flowers addition were prepared for evaluation in the following ratios: 95: 5, 90:10, 85:15. The control represented $100 \%$ wheat flour. Preliminary rheological analyzes indicated a strong influence of the ingredients used on the properties of the dough. The addition of elderflowers, elderberry and blackcurrants significantly increased the values of the dough development time. In the samples with the addition of elder flowers, we also found a higher stability of the dough, on the contrary, the addition of berries of elderberry and also the $15 \%$ addition of chokeberry reduced it. The most significant effect of increasing the addition on the development time and stability of the dough was observed in the samples with the addition of blackcurrant. In contrast to the other samples, the properties of the flour with the addition of elder flowers were comparable with the control flours in protein strength, in starch gelatinization and in the estimated amylase activity. Samples of flour with the addition of lyophilized fruits behaved significantly differently rheologically than flour with the addition of elder flowers. The closest relationship ( $\mathrm{p}<0.001)$ was observed between the torque C3 (starch gelatinization rate) and C4 (stability of the formed gel), also between C3 and the difference C3$\mathrm{C} 2(\mathrm{r}=0.99)$.

Keywords: Elder flowers, Elderberry, Blackcurrant, Chokeberry, Mixolab, Chopin+ protocol, Rheological Properties

\section{INTRODUCTION}

In recent years, more attention has been focused on evaluating the quality of wheat flour and bakery products. In the technology of baking, composite flours based on wheat and other cereals and non-grain seeds have become popular (Švec and Hrušková, 2015). New non-traditional ingredients, for example amaranth, sunflower, quinoa, hemp, chickpeas, lupine, flaxseed, chia, teff, improve the rheological properties of the dough, increase the nutritional value and quality of bread (Rosell et al., 2009; Mironeasa et al., 2012; Švec and Hrušková, 2015). The effect of bioactive substances of several species such as berries - black elderberry (Sambucus nigra L.), blackcurrant fruits (Ribes nigrum L.) and black chokeberry (Aronia melanocarpa L.) (Karjalainen et al., 2009) reduces oxidative stress and strengthens the body's immune system (Aksoylu et al., 2015; Miletić $\boldsymbol{e t}$ al., 2019). Polyphenol-rich plant extracts are emerging as potential ingredients in functional foods and / or beverages (Prpa et al., 2020). Phenolic compounds, particularly the flavonoids and phenolic acids, appears to be the major functional components of berries (Pinto et al., 2010). Numerous studies have shown, that the fruits and flowers of blackberry (Sambucus nigra L.) are an important source of bioactive compounds such as polyphenols and anthocyanins with high antioxidant activity, which significantly affects its health benefits. In recent years it was found that elderberry has antibacterial, antiviral, antidepressant, antitumor and hypoglycemic properties, and to reduce body fat and lipid parameters (Duymus et al., 2014; Mlynarczyk et al., 2018; Ferreira et al., 2020). The content of ascorbic acid ranges between 6 and $25 \mathrm{mg} / 100 \mathrm{~g}$ of elderberry fruit (Kaack and Austed, 1998) and furthermore, elderberry seed flour is a source of alpha-tocopherol and gamma-tocopherol (Fazio, 2013). Minerals are located both in berries and flowers which includes relatively large amounts of potassium, phosphorus, calcium, sodium, and magnesium, and various microelements such as iron, zinc, manganese, and copper (Sidor and Gramza-Michalowska, 2015). The flowers were found to contain a much higher content of most minerals compared to the fruit. Both the fruit and flower of elderberry can be a good source of healthy and high-value products (Mlynarczyk et al., 2020).

Similarly, blackcurrant (Ribes nigrum L.) fruits are a particularly rich source of biologically active compounds, such as anthocyanins, quercetin, proanthocyanins, myricetin, phenolic acids and isorhamnetin (Karjalainen et al., 2009). These flavonoids have been demonstrated to possess neuroprotective activity. In addition, blackcurrant possesses a high content of vitamin $\mathrm{C}$, contributing together with bioactive phenolics to the high antioxidant activity of berries. In addition to antimicrobial, antimutagenic, anti-inflammatory, anti-cancer and antihypertensive properties, blackcurrant berries and leaves showed very strong biological activity, including inhibition of cell proliferation (Puupponen-Pimiä et al., 2005; Tabart et al., 2012; Paunović et al. 2017). Black currant is an important berry for the food industry in Europe, especially for its colour and organoleptic properties, making it a suitable material for various food applications (Karjalainen et al., 2009).

Black chokeberry (Aronia melanocarpa L.) is used as an ornamental plant and as a colorant and food. It is rich in the secondary metabolites such as flavonoids and anthocyanins which has been shown to be important for protection against oxidative stress (Kim et al., 2013; Sójka et al., 2013; Szopa et al., 2017). Fresh chokeberries have a sour, bitter and astringent taste. The bitter taste is due to the content of polyphenolics (phenolic acids, tannins and hot eriodyctiol glucuronide) (Duffy et al., 2016). The main anthocyanins in the black chokeberry are cyanidin 3-Oarabinoside, cyanidin 3-O-galactoside, cyanidin 3-O-glucoside, and cyanidin 3-O-xyloside. These compounds are characterized by many pharmacological effects, such as antioxidant defence, antimicrobial, antiproliferative, antiinflamatory, and modulate hepatic lipid metabolism activities (Kim et al., 2013; Stanisavljevi'c et al., 2015; Bhaswant et al., 2017; Denev et al., 2019). The health benefits of anthocyanins include the prevention and remedy of cardiovascular disease and liver failure, anti-obesity and antidiabetic activity (Kim et al., 2012; Ho et al., 2014; Thilavech and Adisakwattana, 2019). The dried black chokeberry fruits may be used for various applications, particularly functional food ingredients, for example chips or as food additive to improve the biological value of food (Sidor et al., 2021).

However, the stability of anthocyanins depends on many factors, such as structure presence of solvents, temperature, oxygen and enzymes, $\mathrm{pH}$, and other concomitant substances (Klisurova et al., 2019). The largest amount of polyphenols is maintained by freeze-drying, which is considered to be the most desirable drying method (Sidor et al., 2021). Freeze-drying, to a large extent allows for considerable preservation of the components in an unaltered state and prevents damage to the structure of the dried material (Calín-Sánchez et al., 2020) Wheat flour is the important ingredient in the production of various types of bakery products. Monitoring the rheological properties of dough is very important for the overall technology to estimate the mechanical properties of dough and to imitate 
its behaviour during its processing or even to anticipate the quality of the final product (Torbica et al., 2019).

The aim of this work was to characterize the rheological properties of dough prepared from wheat flour and with $5 \%, 10 \%$ and $15 \%$ additions of flowers (Flos sambuci L.) and berries of elderberry (Sambucus nigra L.), blackcurrant (Ribes nigrum L.) and chokeberry (Aronia melanocarpa L.)

\section{MATERIAL AND METHODS}

\section{Samples}

In this study, commercial wheat flour T650 (ash 0.65\%) (MLYN ZRNO, Miroslav Grznár, Slovak Republic) were used. The elderberry (flowers and berries), black currants and chokeberry came from the Botanical Garden of the Slovak University of Agriculture (August-September 2020). Elder flowers (Flos sambuci) were harvested at the end of May 2020 (flat peak $20 \mathrm{~cm}$ in diameter) and loosely dried on sieves $\left(14\right.$ days, at $\left.23^{\circ} \mathrm{C}\right)$, without direct sunlight, with air circulation. The fruits (berries) were harvested when they were fully ripe (colour is considered the most reliable indicator of ripeness) (Lysiak et al., 2014). In the laboratory, the berries were separated from the stems and from the unripe and dry berries. The fruits of elderberry, blackcurrant and chokeberry were lyophilized for 5 days at $-58{ }^{\circ} \mathrm{C}$ (ilShin Lab Co., Ltd., Korea). Dried elder flower and freeze-dried elderberry, blackcurrants and chokeberry were homogenized using a stainless-steel blender (BOSCH TSM6A01, Germany).

Twelve kinds of a mixture of wheat flour with different ratios (flowers and berries of elderberry, black currant and chokeberry) were prepared for evaluation in the following ratios: 95:5, 90:10, 85:15. As a control (C) was used only pure wheat flour (energy value - $1464 \mathrm{~kJ}$, carbohydrate content $-71 \mathrm{~g} / 100 \mathrm{~g}$ of which sugars $-1.59 \mathrm{~g} / 100 \mathrm{~g}$, fibre content $-3.3 \mathrm{~g} / 100 \mathrm{~g}$, protein content $-11 \mathrm{~g} / 100 \mathrm{~g}$, fat content $-1.3 \mathrm{~g} / 100 \mathrm{~g}$ of which saturated $-0.3 \mathrm{~g} / 100 \mathrm{~g})$. The data is guaranteed by the manufacturer. Labeling of samples: FS 5 - flour : Flos sambuci (95:5), FS 10 flour : Flos sambuci (90:10), FS 15 - flour : Flos sambuci (85:15), SN 5 - flour :
Sambucus nigra (95:5),_SN 10 - flour : Sambucus nigra (90:10), SN 15 - flour : Sambucus nigra (85:15), RN 5 - flour : Ribes nigrum (95:5), RN 10 - flour : Ribes nigrum (90:10), RN 15 - flour : Ribes nigrum (85:15), AM 5 - flour : Aronia melanocarpa (95:5), AM 10 - flour : Aronia melanocarpa (90:10), AM 15 - flour : Aronia melanocarpa $(85: 15)$

\section{Rheological properties testing}

The rheological properties of dough were monitored using "Chopin+" protocol on the Mixolab 2 (Chopin Technologies, Villeneuve la Garenne, France) according to ICC No. 173. The experiments were made in duplicate. The Mixolab evaluates in real time the torque $(\mathrm{Nm})$ that is produced by the dough between the blades. The test is based on the preparation of a constant hydrated mass of dough so as, to obtain the target consistency during the first test phase. In the "Chopin +" protocol, the dough weighs 75 grams, and the target consistency is $1.1 \mathrm{Nm}(+/-0.05 \mathrm{Nm})$ (Chopin Technologies Application Team, 2009). Settings of the test: initial state at $30{ }^{\circ} \mathrm{C}$ for $8 \mathrm{~min}$, heating to $90{ }^{\circ} \mathrm{C}$ for $15 \mathrm{~min}\left(4{ }^{\circ} \mathrm{C} / \mathrm{min}\right)$, holding at $90{ }^{\circ} \mathrm{C}$ for 7 min, cooling to $50{ }^{\circ} \mathrm{C}$ for another $10 \mathrm{~min}\left(4^{\circ} \mathrm{C} / \mathrm{min}\right)$ and holding at $50{ }^{\circ} \mathrm{C}$ for 5 min. The mixing speed was kept constant at $80 \mathrm{rpm}$. The whole analysis takes 45 min. Figure 1 shows a typical Mixolab curve, which distinguishes the different stages of dough changes due to both temperature and mixing force. The parameters highlighted in the curve are: $\mathrm{C} 1(\mathrm{Nm})$ - maximum torque during mixing (determines water absorption); $\mathrm{C} 2(\mathrm{Nm})$ - measures the protein attenuation based on temperature and mechanical work; $\mathrm{C} 3(\mathrm{Nm})$ - expresses gelatinization of starch $\mathrm{C} 4(\mathrm{Nm})$ - indicates the stability of the starch gel formed; C5 (Nm) - measures the retrogradation of starch during the cooling phase; differences: $\mathrm{C} 1-\mathrm{C} 2$ indicates the strength of the protein network with increasing heating; $\mathrm{C} 3-\mathrm{C} 2$ corresponds to the gelatinization rate of starch; $\mathrm{C} 3-\mathrm{C} 4$ shows amylase activity and is linked to falling number; C5-C4 corresponds to the anti-stalling effects (retrogradation of starch in the cooling phase), represents the shelf life of the final products (Papoušková et al., 2011).

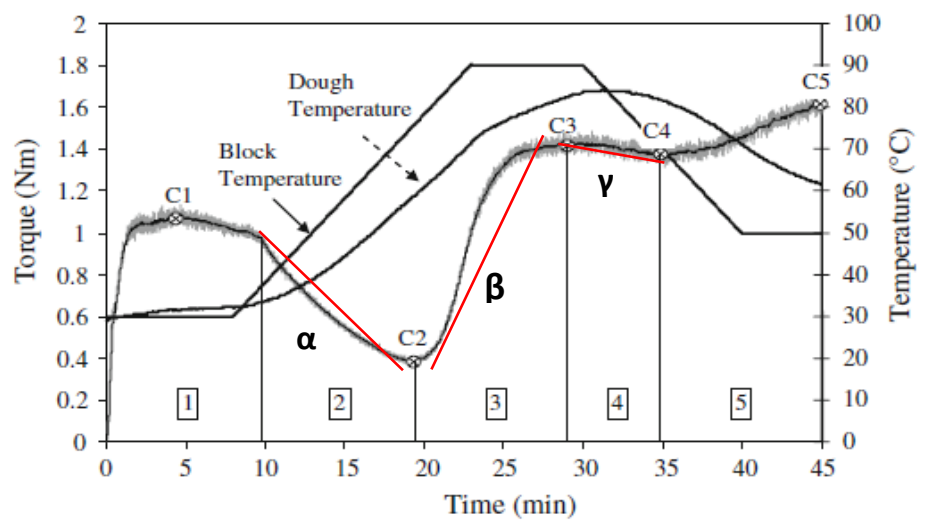

Stage (1) - dough development (constant

temperature $30^{\circ} \mathrm{C}$ );

Stage (2) - thermal weakening of the proteins

Stage (3) - starch gelatinization

Stage (4) - enzymatic activity constant heating rate

Stage (5) - starch retrogradation

Figure 1 A typical Mixolab curve for dough (Ozturk et al., 2008). In addition, the slopes and the angles between ascending and descending curves were calculated. $\alpha$-represents the slope of the curve between the end of the period of $30^{\circ} \mathrm{C}$ and $\mathrm{C} 2$; gives indication about the rate of the proteins thermal weakening; $\beta$ - represents the slope of the curve between $\mathrm{C} 2$ and $\mathrm{C} 3$; gives indications about the gelatinisation rate; $\gamma$ - represents the slope of the curve between $\mathrm{C} 3$ and $\mathrm{C} 4$; gives indications about the rate of enzymatic hydrolysis.

\section{Statistical analysis}

Statistical analysis was carried out using MS Excel 2016 (Microsoft Corporation, Redmond, Washington, USA). The relationships between the parameters (torque points $\mathrm{C} 1, \mathrm{C} 2, \mathrm{C} 3, \mathrm{C} 4, \mathrm{C} 5, \mathrm{C} 1-\mathrm{C} 2, \mathrm{C} 3-\mathrm{C} 2, \mathrm{C} 3-\mathrm{C} 4$ and $\mathrm{C} 5-\mathrm{C} 4)$ were assessed by Pearson's correlation at significance level 0.05 .

\section{RESULTS AND DISCUSSION}

Strong flours, with a higher content of quality gluten, have a greater ability to bind water (higher yield) with longer swelling of individual ingredients. The dough is more stable, easy to process, shapes and does not stick (Robertson and Cao, 2001). Weak flours are less stable and have a lower ability to bind water (lower dough and pastry yield). Conventional types of pastry made from weak flour are usually poorly fermented, have an unsuitable structure and a small volume (Baik and Lee, 2003). Therefore, they are more suitable for baking use, where the creation of a compact spatial gluten network is not required during mixing (e.g. biscuits) (Fustier et al., 2009). The water absorption of the control flour was 65.6 $\%$, which is a high value and indicates the good quality of the control flour used, while with increasing amount of the addition of elder flowers this value increased (FS $5-66.7 \%$, FS $10-69 \%$, FS $15-71.5 \%$ ), on the contrary, other additions reduced the water absorption (SN $5-62.8 \%$, SN $10-61 \%$, SN $15-59 \%$; RN 5 - $65.3 \%$, RN $10-63.7 \%$, RN $15-62.2 \%$ and AM $5-65.3 \%$, AM $10-63.7 \%$, AM $15-62.2 \%$ ). In all cases, the addition of water was associated with the creation of an optimal dough consistency.
Adding elder flowers and non-traditional fruits to wheat flour $(5 \%, 10 \%, 15 \%)$ resulted in differences in the viscoelastic properties of the path (Fig. 2). The Mixolab Profiler shows the standard curve of Mixolab into six indexes of flour quality factors, graded from 0 to 9 (mixing, water absorption, gluten strength, maximum viscosity, amylase resistance and retrogradation) (Chopin Technologies Application Team, 2009). As an indicator of the overall quality of flour proteins, a mixing index is used, which expresses the flour's resistance to kneading (Hadnadev et al., 2011). Flours with added chokeberry reached low mixing values. The mixing index decreased with increasing amount of ingredients (AM 5 - 3, AM 10 - 2, AM 15 - 1). Gluten+ index represents the behavior of the gluten when heating the dough and it is therefore the measure of protein strength. It has to be pointed out that Gluten+ index is not the measure of gluten content The results showed a weakening of the gluten network in all evaluated samples, except AM 10 and AM 15.

The rheological behavior of wheat flour dough (control) and wheat flour with different additions during the Mixolab test are detailed in Tab. 1. Determined Mixolab C1-C5 values for control flour were $1.11 \mathrm{Nm}, 0.56 \mathrm{Nm}, 1.92 \mathrm{Nm}, 2.15$ $\mathrm{Nm}$, and $4.85 \mathrm{Nm}$, respectively. Similar behaviour of Mixolab was reported by Papoušková et al. (2011) in the evaluation of three wheat varieties (C1- C5 averages $1.12 \mathrm{Nm}, 0.46 \mathrm{Nm}, 2.04 \mathrm{Nm}, 1.76 \mathrm{Nm}, 2.44 \mathrm{Nm}$, respectively) and Švec and Hrušková (2015) $(1.10 \mathrm{Nm}, 0.50 \mathrm{Nm}, 2.06 \mathrm{Nm}, 1.69 \mathrm{Nm}$, and $2.54 \mathrm{Nm})$. The difference in the parameter of curve C5 was shown. Banu et al., 2011 published the results of parameter C5 $-3.12 \mathrm{Nm}$ (Romanian commercial samples of wheat flour). Varieties of different technological quality as well as the type of locality and weather conditions contributed to the diverse course of starch retrogradation. 
Table 1 Mixolab characteristics of the flours with additions

\begin{tabular}{|c|c|c|c|c|c|c|}
\hline Sample & $\mathrm{C} 1$ & $\mathrm{C} 2$ & $\mathrm{C} 3$ & $\mathrm{C} 4$ & $\mathrm{C} 5$ & \multirow{2}{*}{$\begin{array}{l}\text { Stability } \pm \text { SD } \\
\text { (min: s) }\end{array}$} \\
\hline & \multicolumn{5}{|c|}{$\mathrm{Nm} \pm \mathrm{SD}$} & \\
\hline $\mathrm{C}$ & $1.11 \pm 0.01$ & $0.56 \pm 0.01$ & $1.92 \pm 0.03$ & $2.15 \pm 0.14$ & $4.85 \pm 0.07$ & $9: 58 \pm 0: 14$ \\
\hline FS 5 & $1.11 \pm 0.03$ & $0.53 \pm 0.04$ & $1.94 \pm 0.06$ & $2.05 \pm 0.13$ & $4.59 \pm 0.10$ & $10: 34 \pm 0: 16$ \\
\hline FS 10 & $1.12 \pm 0.06$ & $0.54 \pm 0.06$ & $1.93 \pm 0.09$ & $1.84 \pm 0.10$ & $4.10 \pm 0.30$ & $10: 15 \pm 0: 58$ \\
\hline FS 15 & $1.14 \pm 0.07$ & $0.53 \pm 0.04$ & $1.72 \pm 0.13$ & $1.40 \pm 0.16$ & $2.97 \pm 0.23$ & $9: 18 \pm 0: 57$ \\
\hline SN 5 & $1.08 \pm 0.06$ & $0.33 \pm 0.03$ & $1.93 \pm 0.10$ & $1.60 \pm 0.11$ & $4.21 \pm 0.13$ & $7: 02 \pm 0: 46$ \\
\hline SN 10 & $1.10 \pm 0.08$ & $0.32 \pm 0.08$ & $1.95 \pm 0.13$ & $1.49 \pm 0.17$ & $4.15 \pm 0.17$ & $6: 35 \pm 0: 28$ \\
\hline SN 15 & $1.06 \pm 0.07$ & $0.31 \pm 0.10$ & $1.85 \pm 0.08$ & $1.24 \pm 0.10$ & $3.92 \pm 0.15$ & $6: 57 \pm 0: 47$ \\
\hline RN 5 & $1.11 \pm 0.04$ & $0.38 \pm 0.09$ & $1.91 \pm 0.40$ & $2.20 \pm 0.06$ & $4.50 \pm 0.10$ & $6: 12 \pm 0: 51$ \\
\hline RN 10 & $1.08 \pm 0.03$ & $0.37 \pm 0.08$ & $2.04 \pm 0.21$ & $2.19 \pm 0.11$ & $4.61 \pm 0.10$ & $7: 47 \pm 0: 41$ \\
\hline RN 15 & $1.03 \pm 0.04$ & $0.48 \pm 0.07$ & $2.15 \pm 0.13$ & $2.08 \pm 0.13$ & $4.41 \pm 0.06$ & $10: 26 \pm 0: 53$ \\
\hline AM 5 & $1.08 \pm 0.03$ & $0.42 \pm 0.09$ & $1.83 \pm 0.24$ & $2.00 \pm 0.08$ & $4.48 \pm 0.08$ & $9: 13 \pm 0: 35$ \\
\hline AM 10 & $1.13 \pm 0.04$ & $0.53 \pm 0.07$ & $4.73 \pm 0.04$ & $4.68 \pm 0.01$ & $4.74 \pm 0.03$ & $9: 42 \pm 0: 51$ \\
\hline AM 15 & $1.22 \pm 0.08$ & $0.61 \pm 0.04$ & $4.48 \pm 0.37$ & $4.42 \pm 0.28$ & $4.71 \pm 0.11$ & $2: 26 \pm 0: 04$ \\
\hline
\end{tabular}

Legend: C - Control, FS (Flos sambuci), SN (Sambucus nigra), RN (Ribes nigrum), AM (Aronia melanocarpa)

The dough development time value for control flour was 1:55 min: $\mathrm{s}$, while the additions of elder flowers (FS), elderberry (SN) and blackcurrant (RN) significantly increased this value, the addition of chokeberry reduced this value (Fig.3). We observed the most significant effect of increasing the addition on the development time of the dough in RN samples. In addition to higher time values of dough development with the addition of elder flowers, we also found higher dough stability at FS 5 and FS 10 compared to control flour. The stability of the dough is considered to be an important indicator of the quality of doughs for bakery processing, especially in connection with the technological process of bread production (leavening, translating, dough resting). We found a gradual increase in the stability of the dough with increasing addition in RN samples. Additions of elderberry reduced the value of dough stability. The dough stability values at AM 5 and AM 10 were similar to control flour, but the $15 \%$ addition of chokeberry (AM 15) significantly reduced this value (Fig.3). The increase in development time and stability of the dough was found by Bojňanská et al. (2020), who researched the effect of adding partially defatted milk thistle flour $(5 \%, 10 \%, 15 \%)$ to a 50:50 mixture of wheat and rye flour.

\section{$95: 5$}

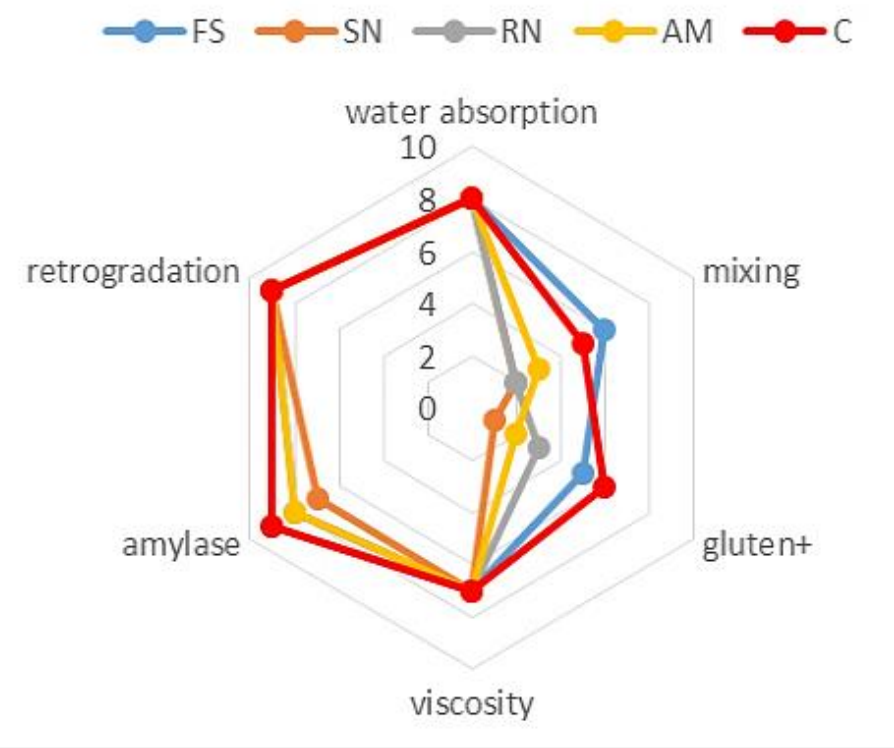

\section{$90: 10$}

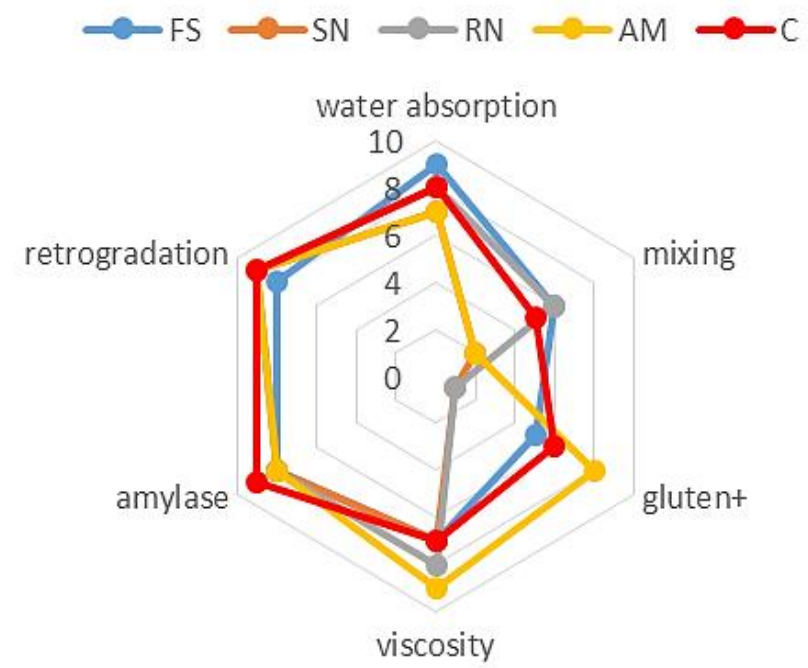

$85: 15$

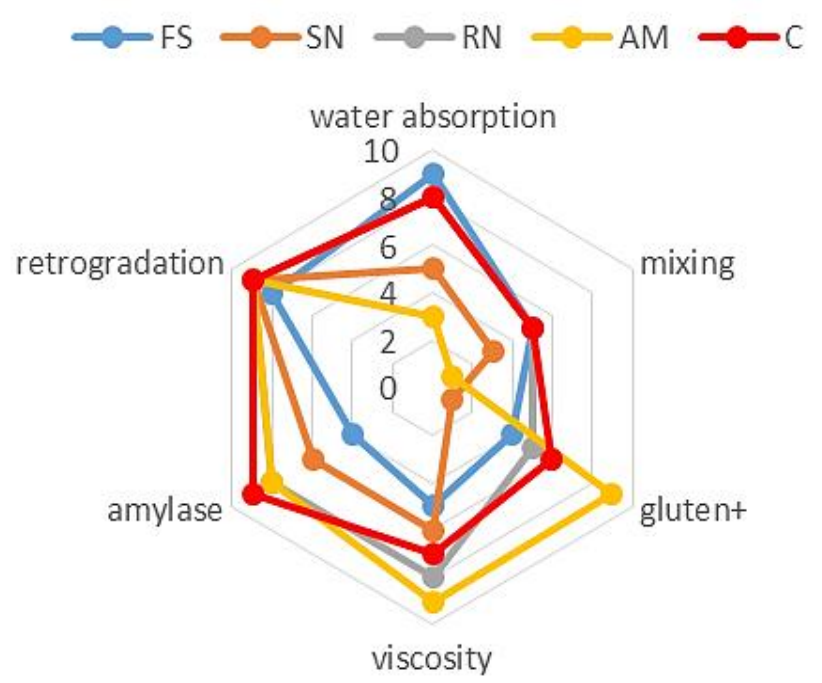

Figure 2 Mixolab profiler (For label legend, see Table 1.) 


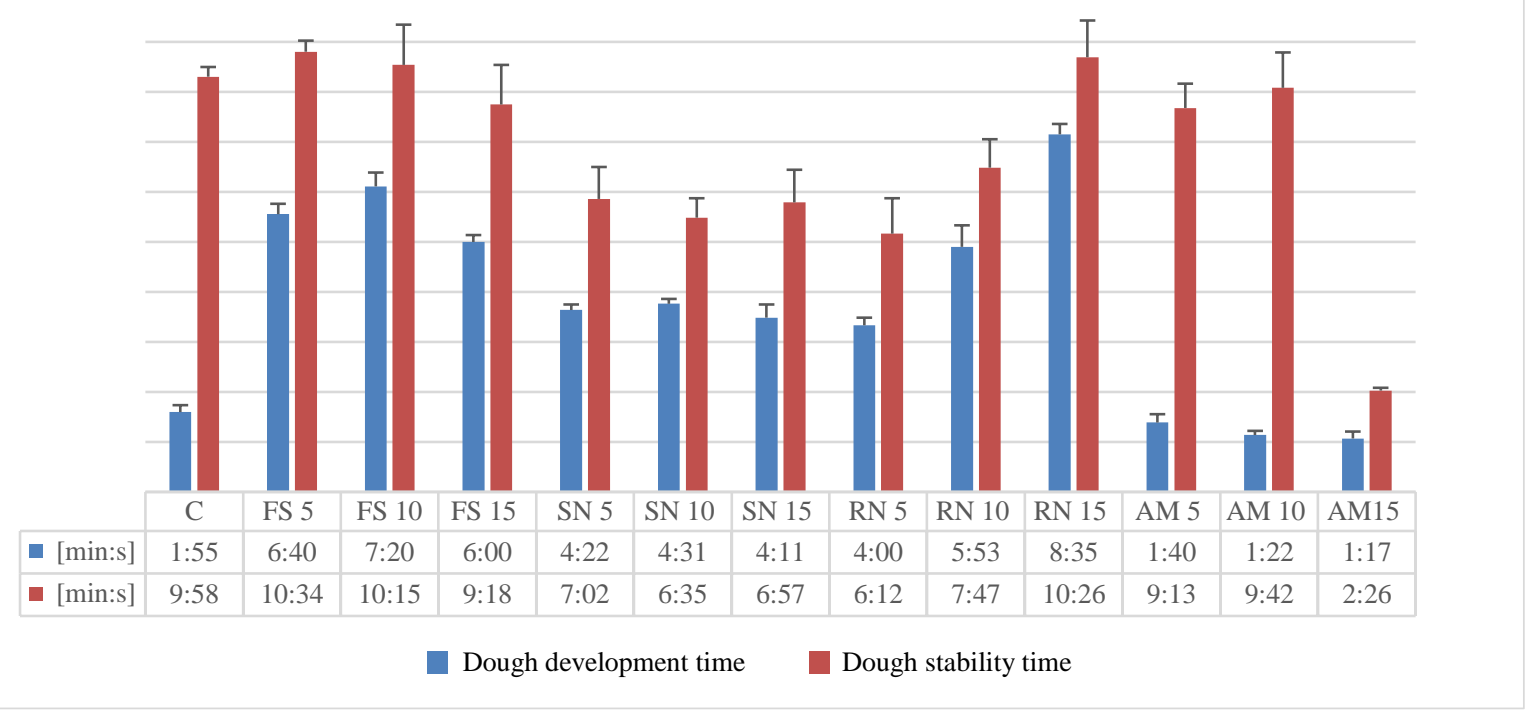

Figure 3 Dough development time and stability

The first part of the Mixolab curve shows the behaviour of the dough during mixing. At this stage, the torque increases until it reaches the maximum (C1). The $\mathrm{C} 1$ value was modelled by the controlled addition of water to the required consistency value of 1.1, with minimal deviations (Tab. 1). At this point, the dough resists deformation for certain time, which determines the stability of the dough The decrease in torque is recorded after the dough stability time, which designate the end of the first phase and the beginning of the second phase. The second phase can start during the initial mixing time, or later, depending on the quality of the flour. At this phase, the proteins are weakened. The longer is the stability time, the better is the protein quality (Hadnadev et al., 2011).

Temperature limitation and current mechanical stress (2nd stage) reduce the torque to the minimum value $(\mathrm{C} 2)$. This value is related to the onset of destabilization of the protein structure (Rosell et al., 2010). The increase in dough temperature led to protein denaturation, which released a large amount of water. Proteins become hydrophobic. In the temperature range of the second phase, the proteolytic enzymes have an optimal activity (Haros et al. 2006, Stoenescu et al., 2010, Banu et al., 2011), represented by the slope $\alpha$ (recorded between C2 - C1). Proteins that are poor in sulfhydryl groups, affect dough stability. They cause dough softening or even degradation. With a higher protein content, the gluten network is stronger and has a higher resistance to shear stress (Kaur et al., 2016). The dough reaches a specific temperature for the start of starch gelatinization, at minimum torque (C2). In the case of the control sample, the minimum torque (C2) was reached faster (16:14 min: s) at a temperature of $54.60{ }^{\circ} \mathrm{C}$. The authors (Banu et al., 2011) state that in the case of a blank sample, the minimum torque $(\mathrm{C} 2)$ was reached faster (17.00 min: s) at a temperature of $55.4{ }^{\circ} \mathrm{C}$ compared to samples with $\alpha$ amylase, where the value $\mathrm{C} 2$ was reached after 18:22 min: s was specific for a higher temperature $\left(57.6-58.2^{\circ} \mathrm{C}\right)$. We found a similar increase in the time to reach the minimum torque $(\mathrm{C} 2)$ at a specifically higher temperature in samples FS $15\left(17: 34\right.$ min: s at $\left.58.60{ }^{\circ} \mathrm{C}\right)$, AM $10\left(17: 26 \mathrm{~min}: \mathrm{s}\right.$ at $\left.57.8^{\circ} \mathrm{C}\right)$ and the highest increase at $\mathrm{AM} 15\left(18: 31 \mathrm{~min}: \mathrm{s}\right.$ at $\left.60.3{ }^{\circ} \mathrm{C}\right)$. The first difference $\mathrm{C} 1-\mathrm{C} 2$ is related to proteins quality. In the control flour, the $\mathrm{C} 2$ values decreased from $1.11 \mathrm{Nm}$ to $0.56 \mathrm{Nm}$ (the difference $\mathrm{C} 1-\mathrm{C} 2$ is $0.55 \mathrm{Nm}$ ). A similar value of torque $\mathrm{C} 2(0.50$ $\mathrm{Nm}$ ) is reported for composite flours by Švec and Hrušková (2015). Similar C2 values were found in flour with the addition of elder flowers (FS 5, FS 10, and FS 15). In flour with the addition of the fruits of elderberry (Sambucus nigrus L.) and blackcurrant (Ribes nigrum, L.), the C2 values decreased on average by $0.71 \mathrm{Nm}$, and in the flour with the addition of chokeberry, the $\mathrm{C} 2$ values decreased on average by $0.63 \mathrm{Nm}$. The Chopin protocol from individual flour measurements with additions is shown in Figures 4 (a, b, c, d).

With increasing temperature $\left(70^{\circ} \mathrm{C}\right)$ starch gelatinization takes place (3rd stage) and at the same time the torque increases until a new maximum value (C3) (Ozturk et al., 2008). Swelling starch granules and hydration cause an increase in dough consistency (Rosell et al. 2007). In the third stage, the starch gelatinization rate is recorded and is defined by the $\beta$ slope (Hadnadev et $\boldsymbol{a l . , 2 0 1 1 ) . ~ T h e ~ e v a l u a t e d ~}$ parameters were slope- $\beta$ (Fig. 5), C3 and difference C3-C2 (Tab.1). Significantly higher values of $\mathrm{C} 3$ torque compared to the control flour were observed in the evaluated flour with $10 \%$ and $15 \%$ addition of chokeberry. The difference $\mathrm{C} 3-\mathrm{C} 2$ increased in flours, especially with the addition of lyophilized fruits ( $\mathrm{SN}, \mathrm{RN}$ and AM), so we evaluate the effect of the dough recipe as significant. In stage 4, a decrease in viscosity is observed due to the physical decomposition of the starch granules at temperatures above $80^{\circ} \mathrm{C}$, resulting to a minimum torque value $(\mathrm{C} 4)$. In this step, the parameters slope- $\gamma, \mathrm{C} 4$, and $\mathrm{C} 4-\mathrm{C} 3$ and enzymatic activity were evaluated. The lowest value of $\mathrm{C} 4$, which shows the stability of the starch gel formed, we determined in samples FS 15, SN 15, RN 15 and AM 5. The same decrease in C4 was observed in the trial mixture 50:35:15 (15\% milk thistle flour) in the work of Bojňanská et al. (2020) and also from the studies of authors Švec and Hrušková (2015), where for the standard M, C4 parameter reached value of $1.59 \mathrm{Nm}$, and for others $\mathrm{K} 1$ hemp flour composites a gradual diminishing of $7 \%$ was observed. In this case, was proved a dependence of determined values on dough formula. We recorded a significantly higher value of $\mathrm{C} 4$ in flour with the addition of chokeberry (AM 10 and AM 15). Viscous behaviour of material heated approximately to $80^{\circ} \mathrm{C}$ demonstrated the highest variability. An interesting finding was that in the flour samples with the addition of elderberry (SN) we recorded a sudden decrease in the value of torque with an increase in temperature above 80 ${ }^{\circ} \mathrm{C}$ (from $29 \mathrm{~min}$.). The decrease was more pronounced with increasing amount of addition (1.6 Nm, 1.49 Nm, 1.24 Nm) (Fig. 4 b) and also had a significant effect on the slope of the curve - slope- $\gamma$, which provides data on the rate of enzymatic hydrolysis (Fig. 5).

Maximum torque (C5) is result of the decrease in the temperature produces an enhancement in the dough consistency (stage 5th) (Ozturk et al., 2008). The degree of starch retrogradation for the tested flours with additions showed similar differences as the stability of the starch gel. We found the lowest C5 values in samples FS 15, SN 15 and RN 15. The lowest difference of C5-C4 compared to the control $(2.696 \mathrm{Nm})$ was found in AM $10(0.061 \mathrm{Nm})$ and AM $15(0.287 \mathrm{Nm})$.

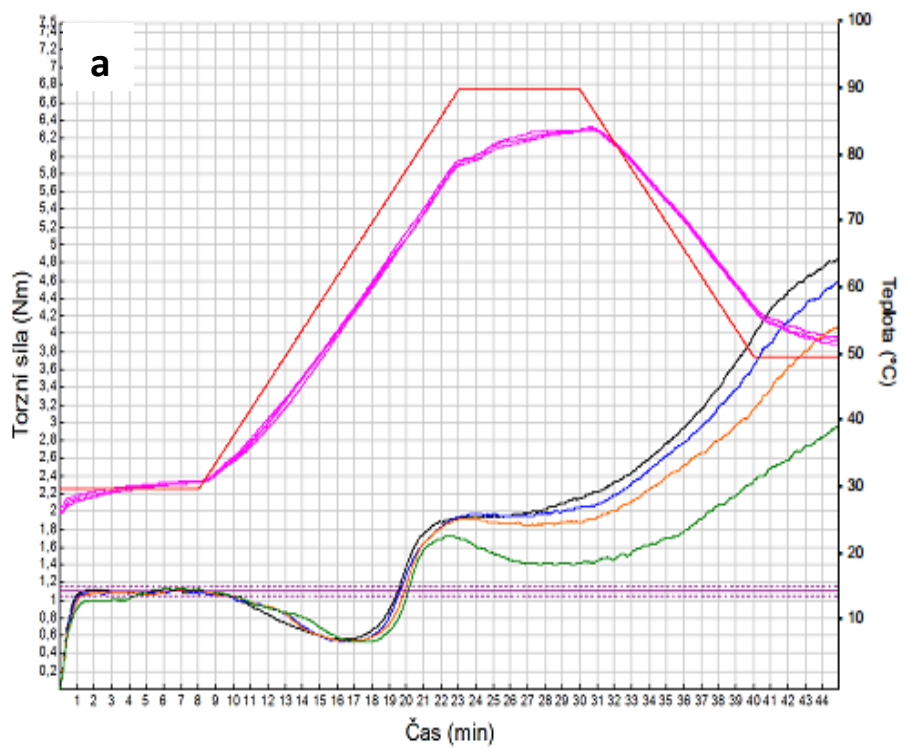



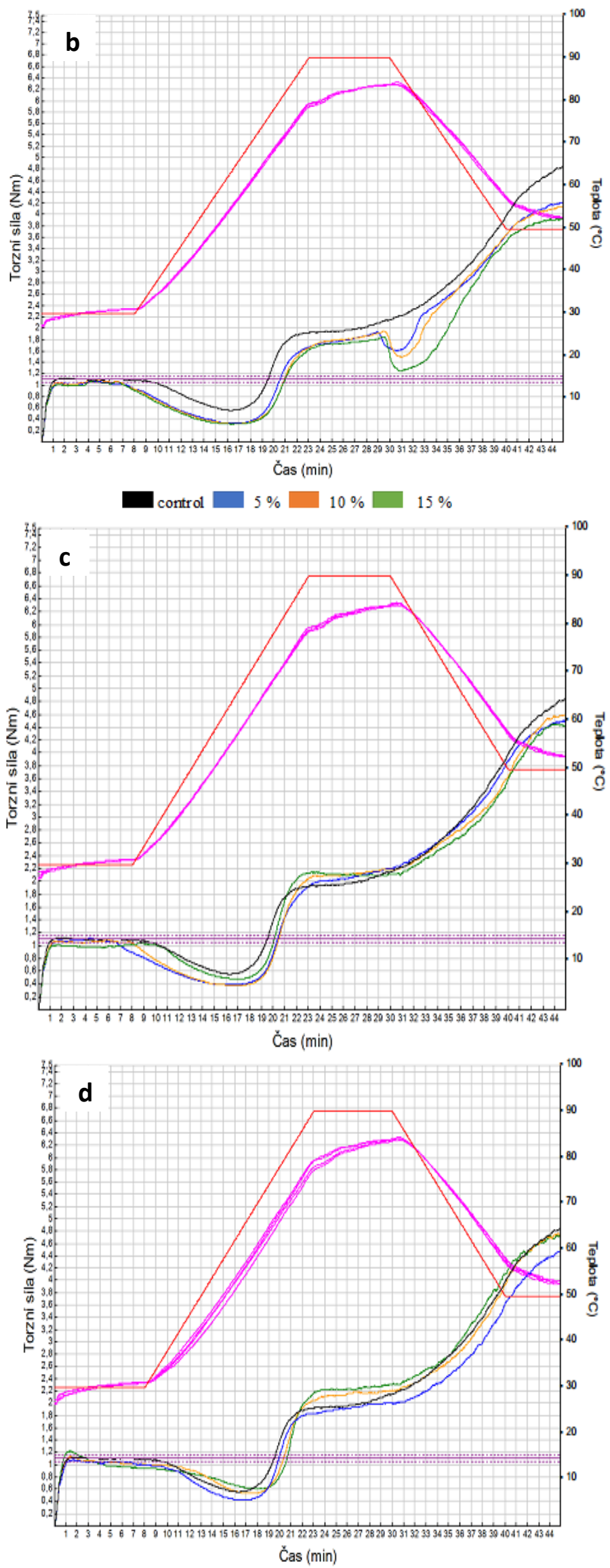

Figure 4 Mixolab curve Chopin+ protocol - a: flour + elder flowers (Flos sambuci L.), b: flour + elderberry (Sambucus nigra L.), b: flour + blackcurrant (Ribes nigrum L.), d: flour + chokeberry (Aronia melanocarpa L.)
The properties of the flour with the addition of elder flowers (FS) were comparable to control (C) in protein strength (difference C1-C2: $0.57,0.58,0.61 \mathrm{Nm}$ vs. 0.56 $\mathrm{Nm}$ ), in starch gelatinization (C3-C2 between 1.20 and $1.41 \mathrm{Nm}$ vs. $1.36 \mathrm{Nm}$ ) and in the estimated amylase activity (C3-C4 between 0.08 and $0.32 \mathrm{Nm}$ vs. 0.22 ). Among calculated pair subtractions of torque points the SN, RN and AM flour composites different from the control flour in protein strength $(\mathrm{C} 1-\mathrm{C} 2)$ and in starch gelatinization (C3-C2), especially AM 10 and AM 15 (4.21 Nm, $4.48 \mathrm{Nm}$ vs. $1.35 \mathrm{Nm}$ ).

The difference was also manifested by amylase activity (C3-C4; SN between 0.33 and $0.61 \mathrm{Nm}$ vs. $0.23 \mathrm{Nm}$; $\mathrm{AM}$ between 0.05 and $0.16 \mathrm{Nm}$ ) and the rate of retrogradation of starches $(\mathrm{C} 5-\mathrm{C} 4)$ mainly in AM 10 samples and AM $15(0.06$ and $0.29 \mathrm{Nm}$ vs. $2.70 \mathrm{Nm}$ ).

Figure 5 documents the slopes $\alpha, \beta$ and $\gamma$ during the dough mixing process. The results confirmed significantly different gelatinization characteristics and enzymatic hydrolysis compared to control flour, especially in flours with the addition of elderberry (SN 5, SN 10, SN 15) and also flours with the addition of chokeberry (AM 10, AM 15).

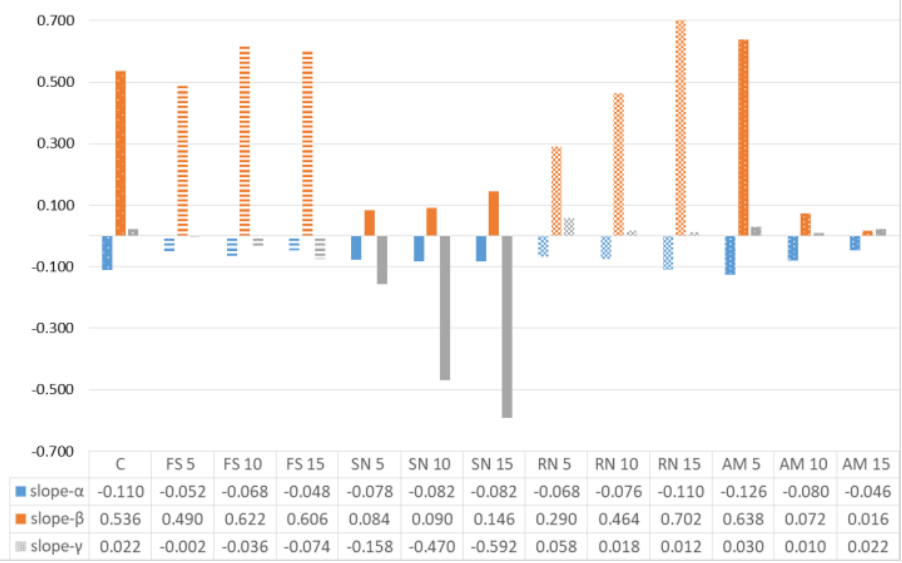

Figure 5 Slope alpha, beta and gamma during the mixing process of dough

\section{Interrelations of the Mixolab parameters}

Correlation analysis of evaluated quality features.

Samples of flour with the addition of lyophilized fruits of elderberry, blackcurrant and chokeberry behaved significantly differently rheologically than flour with the addition of elder flowers, so we were interested in mutual correlations in these samples (Tab. 2). To evaluate the exchangeability of Mixolab properties among themselves, a correlation matrix was calculated within a set of 9 monitored items.

Papouskova et al. (2011) published a work where all properties of Mixolab, which related to the quality of 24 samples of wheat variety, were correlated with each other - the proven binding is in the intervals $\langle 90.93 ;-0.39\rangle \mathrm{a}\langle 0.51 ; 0.95\rangle$. Positive relationships between all five C's were demonstrated by Xie $\boldsymbol{e t}$ al. (2011) within a set of 183 rice varieties (rice flour). The strongest correlation was found for the $\mathrm{C} 1$ - C2 pair $(\mathrm{r}=0.81, \mathrm{p}<0.01)$ the closest relationship $(\mathrm{p}<0.001)$ was observed between the torque $\mathrm{C} 3$ (starch gelatinization rate) and $\mathrm{C} 4$, also between $\mathrm{C} 3$ and the difference C3-C2 $(r=0.99)$. For the latter features pair, Švec and Hrušková (2015) mentioned comparable proximity in hemp composites $(r=0.96, p<0.01)$. The protein thermal weakening (feature $\mathrm{C} 2$ ) was positively correlated with $\mathrm{C} 3, \mathrm{C} 4$, $\mathrm{C} 5$ and the difference $\mathrm{C} 3-\mathrm{C} 2$, on the contrary, a moderately negative correlation was found with the difference $\mathrm{C} 1-\mathrm{C} 2$ and $\mathrm{C} 5-\mathrm{C} 4$. Another relationship between torque points $\mathrm{C} 4$ and $\mathrm{C} 5$ was moderately significant $(\mathrm{r}=0.81, \mathrm{p}<0.01)$. Study of the effect of grape seed flour on wheat flour revealed a middle strong correlation between parameters C4 and C5 ( $\mathrm{r}=0.63)$ (Mironeasa et al., 2012). Hemp flour addition to those torque points exchangeability was markedly stronger $(\mathrm{r}=0.95, \mathrm{p}$ $<0.01)$. Higher evidence was also confirmed in their work by Papoušková $\boldsymbol{e t}$ al . (2011) $(\mathrm{r}=0.93, \mathrm{p}<0.01)$. The $\mathrm{C} 5-\mathrm{C} 4$ difference significantly negatively correlated with all torque values and also with the $\mathrm{C} 3-\mathrm{C} 2$ difference ( $\mathrm{r}$ between 0.72 and -0.99 ) 
Table 2 Correlation analysis between the Mixolab curve features (torque points) - flour + lyophilized berries of elderberry (Sambucus nigra L.), Blackcurrant (Ribes nigrum L.) and chokeberry (Aronia melanocarpa L.)

\begin{tabular}{|c|c|c|c|c|c|c|c|c|c|}
\hline $\mathrm{N}=9$ & $\mathrm{C} 1$ & $\mathrm{C} 2$ & $\mathrm{C} 3$ & $\mathrm{C} 4$ & $\mathrm{C} 5$ & $\mathrm{C} 1-\mathrm{C} 2$ & $\mathrm{C} 3-\mathrm{C} 2$ & $\mathrm{C} 3-\mathrm{C} 4$ & $\mathrm{C} 5-\mathrm{C} 4$ \\
\hline $\mathrm{C} 1$ & 1 & & & & & & & & \\
\hline $\mathrm{C} 2$ & $\mathrm{~ns}$ & 1 & & & & & & & \\
\hline $\mathrm{C} 3$ & $0.75^{*}$ & $0.85^{* *} *$ & 1 & & & & & & \\
\hline $\mathrm{C} 4$ & $0.75^{*}$ & $0.89 * *$ & $0.97 * * *$ & 1 & & & & & \\
\hline $\mathrm{C} 5$ & ns & $0.78^{*}$ & ns & $0.81 * *$ & 1 & & & & \\
\hline $\mathrm{C} 1-\mathrm{C} 2$ & ns & $-0.85^{* *}$ & $\mathrm{~ns}$ & $\mathrm{~ns}$ & $\mathrm{~ns}$ & 1 & & & \\
\hline $\mathrm{C} 3-\mathrm{C} 2$ & $0.75^{*}$ & $0.82 * *$ & $0.99 * * *$ & $0.96^{* * *}$ & ns & ns & 1 & & \\
\hline C3-C4 & ns & Ns & ns & ns & $-0.78 *$ & $\mathrm{~ns}$ & ns & 1 & \\
\hline $\mathrm{C} 5-\mathrm{C} 4$ & $-0.76^{*}$ & $-0.87 * *$ & $-0.99 * * *$ & $-0.98 * * *$ & $-0.72 *$ & ns & $-0.99 * * *$ & ns & 1 \\
\hline
\end{tabular}

Legend: *,**, *** - significant at $\mathrm{p}<0.05, \mathrm{p}<0.01$ and $\mathrm{p}<0.001$ respectively; ns - non-significant.

\section{CONCLUSION}

In this work we characterize the rheological properties of dough prepared from wheat flour and with $5 \%, 10 \%$ and $15 \%$ additions of flowers (Flos sambuci L.) and fruits of elderberry (Sambucus nigra L.), blackcurrant (Ribes nigrum L.) and chokeberry (Aronia melanocarpa L.). Preliminary rheological analyzes indicated a strong influence of the additives used on the properties of the dough. Adding elder flowers and non-traditional fruits to wheat flour, resulted in differences in the viscoelastic properties of the path. The addition of elder flowers, elderberries and blackcurrants significantly increased the values of the dough development time, but the addition of chokeberry decreased this value. In the samples with the addition of elderflowers, we also found a higher stability of the dough, on the contrary, the addition of elderberry fruits and also the $15 \%$ addition of chokeberry reduced it. The flours with added fruits of elderberry, blackcurrant and chokeberry differed from the pure wheat flour in protein strength and starch gelatinization (values increased). Viscous behaviour of the composite material heated to about $80{ }^{\circ} \mathrm{C}$ showed the highest variability. The difference was also manifested by amylase activity in the samples with the addition of black base (more pronounced decrease with increasing amount of addition) and chokeberry (significantly higher values with $10 \%$ and $15 \%$ addition) as well as the rate of starch retrogradation mainly in samples with $10 \%$ and $15 \%$ chokeberry.

Due to the rheological properties of the dough, the results suggest that the verified fruit and elder flower additives can be used for the preparation of bakery products (including sweet variants) as well as long-lasting pastries (biscuits). Even in connection with the color of the dough, this non-traditional fruit can increase the attractiveness of the products. Further evaluation is needed in this area, but the test results obtained can be an important source of information for manufacturers when designing new products with increased health benefits.

Acknowledgments: This work was supported by project APVV-18-0312 and Drive4SIFood 313011 V336.

\section{REFERENCES}

Aksoylu, Z., Çağindi, Ö, \& Köse, E. (2015). Effects of blueberry, grape seed powder and poppy seed incorporation on physicochemical and sensory properties of biscuit. Journal of Food Quality, 38, 164-174. https://doi.org/10.1111/jfq.12133

Baik, B. K. and Lee, M. R.. (2003). Effect of starch amylose content of wheat on textural properties of white salted noodles. Cereal Chemistry, 80 (3), 304-309. https://doi.org/10.1094/CCHEM.2003.80.3.304

Banu, I., Stoenescu, G., Ionescu, V., \& Aprodu, I. (2011). Estimation of the baking quality of wheat flours based on rheological parameters of the Mixolab curve Czech Journal of Food Science, 29, 35-44. https://doi.org/10.17221/40/2009CJFS

Bhaswant, M., Shafie, S.R., Mathai, M.L., Mouatt, P., Brown, L. (2017) Anthocyanins in chokeberry and purple maize attenuate diet-induced metabolic syndrome in rats. Nutrition, 41, 24-31. https://doi.org/10.1016/j.nut.2016.12.009. Bojňanská, T., Vollmannová, A., \& Musilová, J. (2020). Milk thistle flour effect on dough rheological properties. Potravinarstvo Slovak Journal of Food Sciences, 14, 788-797. https://doi.org/10.5219/1365

Calín-Sánchez, Á., Lipan, L.; Cano-Lamadrid, M., Kharaghani, A., Masztalerz, K., Carbonell-Barrachina, Á.A., Figiel, A. (2020). Comparison of traditional and novel drying techniques and its effect on quality of fruits, vegetables and aromatic herbs. Foods, 9, 1261. https://doi.org/10.3390/foods9091261

Denev, P., Č́íž, M.; Kratchanova, M., Blazheva, D. (2019). Black chokeberry (Aronia melanocarpa) polyphenols reveal different antioxidant, antimicrobial and neutrophil-modulating activities. Food Chem., 284, 108-117. https://doi.org/10.1016/j.foodchem.2019.01.108.

Duffy, V. B., Rawal, S., Park, J., Brand, M. H., Sharafi, M., \& Bolling, B. W. (2016). Characterizing and improving the sensory and hedonic responses to polyphenol-rich aronia berry juice. Appetite, 107, 116-125. https://doi.org/10.1016/j.appet.2016.07.026
Duymus, H.G., Göger, F., Ba,ser, K.H. (2014). In vitro antioxidant properties and anthocyanin compositions of elderberry extracts. Food Chem., 155, 112-119. https://doi.org/10.1016/j.foodchem.2014.01.028.

Fazio, A., Plastina, P., Meijerink, J., Witkamp, R.F., Gabriele, B. (2013) Comparative analyses of seeds of wild fruits of Rubus and Sambucus species from Southern Italy: Fatty acid composition of the oil, total phenolic content, antioxidant and anti-inflammatory properties of the methanolic extracts. Food Chem. 140, 817-824. https://doi.org/10.1016/i.foodchem.2012.11.010.

Ferreira, S.S.; Silva, P.; Silva, A.M.; Nunes, F.M. 2020. Effect of harvesting year and elderberry cultivar on the chemical composition and potential bioactivity: A $\begin{array}{llll}\text { three-year study. } & \text { Food } \quad \text { Chem., } & 302, & 125-366 .\end{array}$ https://doi.org/10.1016/j.foodchem.2019.125366.

Fustier, P., Castaigne, F., Turgeon, S. L. and Biliaderis, C. G. (2009). Impact of commercial soft wheat flour stream on dough rheology and quality attributes of cookies. Journal of Food Engineering, 90 (2), 228-237. https://doi.org/10.1016/j.jfoodeng.2008.06.026

Hadnadev, T. D., Pojic, M., Hadnadev, M., Torbica, A. 2011. The Role of Empirical Rheology in Flour Quality Control, Chapters, in: Isin Akyar (ed.), Wide Spectra of Quality Control, IntechOpen. DOI: 10.5772/24148. https://www.researchgate.net/publication/221913320

Haros M., Ferrer A., Rosell C. M. (2006). Rheological behaviour of whole wheat flour, In: IUFoST - World Congress 13th World Congress of Food Science \& Technology. https://doi.org/10. 1051/UFoST:20060681

Ho, G., Bräunlich, M., Austarheim, I., Wangensteen, H., Malterud, K., Slimestad, R., \& Barsett, H. (2014). Immunomodulating activity of Aronia melanocarpa polyphenols. International Journal of Molecular Sciences, 15, 11626-11636. https://doi.org/10.3390/ijms1 50711626

Chopin Technologies Application Team. (2009). Mixolab applications handbook, Rheological and Enzymatic Analysis (No. 28), Chopin Applications Laboratory, Villeneuve la Garenne, France, www.chopin.fr

Kaack, K.; Austed, T. (1998). Interaction of vitamin C and flavonoids in elderberry (Sambucus nigra L.) during juice processing. Plant Foods Hum. Nutr. 1998, 52, 187-198. https://doi.org/10.1023/A:1008069422202

Karjalainen, R., Anttonen, M., Saviranta, N., Stewart, D., McDougall, G.J., Hilz, H., Mattila, P. and Törrönen, R. (2009). A review on bioactive compounds in black currants (Ribes nigrum L.) and their potential health-promoting properties Acta Hortic. 839 ,

https://doi.org/10.17660/ActaHortic.2009.839.38

Kaur, A., Shevkani, K., Katyal, M., Singh, N., Ahlawat, A. K., Singh, A. M. (2016). Physicochemical and rheological properties of starch and flour from different durum wheat varieties and their relationships with noodle quality. Journal of Food Science and Technology, 53(4), 2127-2138. https://doi.org/10.1007/s13197-016-2202-3

Kim, B.; Ku, C.S.; Pham, T.X.; Park, Y.; Martin, D.A.; Xie, L.; Taheri, R.; Lee, J.; Bolling, B.W. (2013). Aronia melanocarpa (chokeberry) polyphenol-rich extract improves antioxidant function and reduces total plasma cholesterol in apolipoprotein E knockout mice. Nutr. Res. 33, 406-413. https://doi.org/10.1016/j.nutres.2013.03.001

Kim, H. G., Kim, G.-S., Park, S., Lee, J. H., Seo, O. N., Lee, S. J., Kim, J. H.,Shim, J.-H., El-Aty, A. M. A., Jin, J. S., Shin, S. C. (2012). Flavonoid profiling in three citrus varieties native to the Republic of Korea using liquid chromatography coupled with tandem mass spectrometry: Contribution to overall antioxidant activity. Biomedical Chromatography, 26(4), 464-470. https://doi.org/10.1002/bmc.1688

Klisurova, D., Petrova, I., Ognyanov, M., Georgiev, Y., Kratchanova, M., Denev, P. (2019). Co-pigmentation of black chokeberry (Aronia melanocarpa) anthocyanins with phenolic co pigments and herbal extracts. Food Chem. 279, 162-170. https://doi.org/10.1016/j.foodchem.2018.11.125.

Lysiak, G., Kurlus, R., Zydlik, Z., \& Walkowiak-Tomczak, D. (2014). Apple skin colour changes during harvest as an indicator of maturity. Acta Scientiarum $\begin{array}{lllll}\text { Polonorum Hortorum } & \text { Cultus, } & 13 & \text { (3), } & \text { 71-83. }\end{array}$ https://czasopisma.up.lublin.pl/index.php/asphc/article/view/2736

Miletić, N., Mitrović, O., Popović, B., Mašković, P., Mitić, M., \& Petković, M. (2019). Chemical changes caused by air drying of fresh plum fruits. International 
Food Research Journal, 26, 1191-1200. http://www.ifrj.upm.edu.my/26\%20(04)\%202019/9\%20-\%20IFRJ181411.R1-

Final.pdf

Mironeasa, S., Codina, G. G., \& Mironeasa, C. (2012). The effect of wheat flour substitution with grape seed flour on the rheological parameters of the dough assessed by Mixolab. Journal of Texture Studies, 43, 40-48. https://doi.org/10.1111/j.1745-4603.2011.00315.x

Mlynarczyk, K., Walkowiak-Tomczak, D., Lysiak, G. P. (2018). Bioactive properties of Sambucus nigra L. as a functional ingredient for food and pharmaceutical industry. Journal of Functional Foods, 40, 377-390. https://doi.org/10.1016/j.jff.2017.11.025.

Mlynarczyk, K., Walkowiak-Tomczak, D., Staniek, H., Kidón, M., .Lysiak, G. P. (2020). The Content of Selected Minerals, Bioactive Compounds, and the Antioxidant Properties of the Flowers and Fruit of Selected Cultivars and Wildly Growing Plants of Sambucus nigra L. Molecules, 25, 876; https://doi.org/10.3390/molecules25040876

Ozturk, S., Kahraman, K., Tiftik, B. (2008). Predicting the cookie quality of flours by using Mixolab ${ }^{\circledR}$. Eur Food Res Technol 227, 1549-1554 (2008). https://doi.org/10.1007/s00217-008-0879-x

Papouskova, L., Capouchova, I., Kostelanska, M., Skeríkova, A., Prokinova, E., Hajslova, J. (2011). Changes in baking quality of winter wheat with different intensity of fusarium spp. contamination detected by means of new rheological system Mixolab. Czech Journal of Food Science, 29, 420-429. https://doi.org/10.17221/426/2010-CJFS

Paunović, S.M., Mašković, P., Nikolić, M., Miletić, R. (2017). Bioactive compounds and antimicrobial activity of black currant (Ribes nigrum L.) berries and leaves extract obtained by different soil management system, Scientia Horticulturae, $\quad 222, \quad 69-75, \quad$ ISSN $\quad$ 0304-4238, https://doi.org/10.1016/j.scienta.2017.05.015.

Pinto, M.S., Kwon, Y., Apostolidis, E., Lajolo, F. M., Genovese, M. I., Shetty, K. (2010). Evaluation of red currants (Ribes Rubrum L.), black currants (Ribes Nigrum L.), red and green gooseberrie (Ribes Uva-Crispa) for potential management of type 2 diabetes and hypertension using in vitro models. Journal of Food Biochemistry 34, 639-660. https://doi.org/10.1111/j.17454514.2009.00305.x

Prpa, E. J. Bajka, B. H. Ellis, P. R. Butterworth, P. J. Corpe, C. P. Hall, W. L. (2020). A systematic review of in vitro studies evaluating the inhibitory effects of polyphenol-rich fruit extracts on carbohydrate digestive enzymes activity: a focus on culinary fruits consumed in Europe, Critical Reviews in Food Science and Nutrition, https://doi.org/10.1080/10408398.2020.1808585

Puupponen-Pimiä, R., Nohynek, L., Alakomi, H.L., Oksman-Caldentey, K.M (2005). Bioactive berry compounds-novel tools against human pathogens (review) Appl Microbiol. Biotechnol. 67, 8-18. https://doi.org/10.1007/s00253-004-1817-x Robertson, G. H. and Cao, T. K. (2001). Farinograph Responses for Wheat Flour Dough Fortified with Wheat Gluten Produced by Cold-Ethanol or Water Displacement of Starch. Cereal Chemistry, 78(5), 538-542. https://doi.org/10.1094/CCHEM.2001.78.5.538

Rojas, J. A., Rosell, C. M., Benedito de Barber, C. (1999). Pasting properties of different wheat flour-hydrocolloid systems, Food Hydrocolloids, 13(1), 27-33, ISSN 0268-005X. https://doi.org/10.1016/S0268-005X(98)00066-6

Rosell, C. M., Cortez, G., \& Repo-Carrasco, R. (2009). Bread making use of andean crops quinoa, kaniwa, kiwicha, and tarwi. Cereal Chemistry, 86 (4), 386392. https://doi.org/10.1094/CCHEM-86-4-0386

Rosell, C.M., Santos, E., Collar, C. (2010). Physical characterization of fiberenriched bread doughs by dual mixing and temperature constraint using the Mixolab $^{\circledR}$. Eur Food Res Technol 231, 535-544. https://doi.org/10.1007/s00217010-1310-y

Sidor A, Drożdżyńska A, Brzozowska A, Gramza-Michałowska A. (2021). The Effect of Plant Additives on the Stability of Polyphenols in Dried Black Chokeberry (Aronia melanocarpa) Fruit. Foods. 10(1), 44 https://doi.org/10.3390/foods10010044

Sidor, A., Gramza-Michałowska, A. (2015). Advanced research on the antioxidant and health benefit of elderberry (Sambucus nigra) in food-a review. J. of Funct. Foods. 18, Part B, 941-958. https://doi.org/10.1016/i.jff.2014.07.012

Sójka, M., Kołodziejczyk, K., \& Milala, J. (2013). Polyphenolic and basic chemical composition of black chokeberry industrial by-products. Industrial Crops and Products, 51, 77-86. https://doi.org/10.1016/j.indcr op.2013.08.051

Stanisavljevi'c, N., Samardži'c, J., Jankovi'c, T., Šavikin, K., Mojsin, M. Topalovi'c, V., Stevanovi'c, M. (2015). Antioxidant and antiproliferative activity of chokeberry juice phenolics during in vitro simulated digestion in the presence of food matrix. Food Chem. 175, 516-522. https://doi.org/10.1016/j.foodchem.2014.12.009

Stoenescu, G., Ionescu, V., Vasilean, I., Aprodu, I. \& Banu, I. (2010). Prediction the Quality of Industrial Flour Using the Mixolab Device, BulletinoUniversity Agricultural Sciences and Veterinary Medicine Cluj-Napoca. Agriculture, Vol. 67, No. 2, pp. 429- 434, ISSN 1843-5386

Švec, I., Hrušková, M. (2015). The Mixolab parameters of composite wheat/hemp flour and their relation to quality features. LWT - Food Science and Technology, 60(1), 623-629. https://doi.org/10.1016/j.1wt.2014.07.034
Szopa, A., Kokotkiewicz, A., Kubica, P., Banaszczak, P., Wojtanowska- Krośniak, A., Krośniak, M., Marzec-Wróblewska, U., Badura, A., Zagrodzki, P., Bucinski, A., Luczkiewicz, M., \& Ekiert, H. (2017). Comparative analysis of different groups of phenolic compounds in fruit and leaf extracts of Aronia sp.: A. melanocarpa, A. arbutifolia, and A. xprunifolia and their antioxidant activities. European Food Research and Technology, 243, 1645-1657. https://doi.org/10.1007/s0021 7-0172872-8

Tabart, J., Franck, T., Kevers, C., Pincemail, J., Serteyn, D., Defraigne, J.O., Dommes, J. (2012). Antioxidant and anti-inflammatory activities of Ribes nigrum
extracts.
Food
Chem.
131 ,
1116-1122.

https://doi.org/10.1016/j.foodchem.2011.09.076.

Thilavech, T., Adisakwattana, S. (2019). Cyanidin-3-rutinoside acts as a natura inhibitor of intestinal lipid digestion and absorption. BMC Complement. Altern. Med., 19, 1-10. https://doi.org/10.1186/s12906-019-2664-8

Torbica, A., Belović, M., Tomić, J. (2019). Novel breads of non-wheat flours. Food Chemistry. 282, 134-140. https://doi.org/10.1016/j.foodchem.2018.12.113

Xie, L., Chen, N., Tang, S., Luo, J., Jiao, G., \& Hu, P. (2011). Use of Mixolab in predicting rice quality. Cereal Chemistry, 88(4), 333-336. https://doi.org/10.1094/CCHEM-06-10-0090 